\title{
LOW (NOT HIGH) TRAIT ANGER IS A PERSONAL STRENGTH IN ADOLESCENTS
}

\author{
BAJA (NO ALTA) IRA RASGO ES UNA \\ FORTALEZA PERSONAL EN ADOLESCENTES
}

\author{
RAÚl José AlCÁZAR-OlÁN ${ }^{1}$, ClaUdia GonZÁlEZ-FraGOSO², \\ DAVID JIMÉNEZ-RODRÍGUEZ ${ }^{2}$, AND JOSÉ LUIS ROJAS-SOLIS ${ }^{3}$
}

Cómo referenciar este artículo/How to reference this article:

Alcázar-Olán R. J., González-Fragoso, C., Jiménez-Rodríguez, D., \& Rojas-Solís, J. L. (2018). Low (not High) Trait Anger is a Personal Strength in Adolescents [Baja (no alta) Ira Rasgo es una fortaleza personal en adolescentes]. Acción Psicológica, 15(2), 83-94. https://doi.org/10.5944/ap.15.2.21748

\begin{abstract}
Low trait anger (the tendency to stay calm to cope with frustrating everyday situations) is a personal strength because it constitutes a good life for oneself and for others, and it is related to mental health. Its counterpart is high trait anger, defined as intense and chronic irritability, which usually has detrimental effects. The purpose of this study was to test three hypotheses in adolescents with high $(n=94)$ and low trait anger $(n=140)$, with a mean age of
\end{abstract}

Correspondence address: Raúl José Alcázar-Olán. Universidad Iberoamericana Puebla, México.

Email: raul.alcazar@iberopuebla.mx

ORCID: Raúl José Alcázar-Olán (http://orcid.org/0000-0001-9439-6293), Claudia González-Fragoso (http://orcid.org/0000-0002-8400-6033), David Jiménez-Rodríguez (http://orcid.org/0000-0002-2686-2384) y José Luis Rojas-Solis (http://orcid.org/0000-0001-6339-4607).

${ }^{1}$ Universidad Iberoamericana Puebla, México.

${ }^{2}$ Universidad Autónoma del Estado de Hidalgo, México.

${ }^{3}$ Benemérita Universidad Autónoma de Puebla, México.

Retrieved: July 12, 2018.

Aceptado: September 25, 2018. 
result, supported the three hypotheses. Aggression and social skills did not differ according to gender. However, female participants experienced higher levels of trait anger than did male participants.

Keywords: Aggression; Anger; Parental practices; Personality; Social skills.

\section{Introduction}

People differ in their tendencies to experience anger (Kuppens, 2005; Wilkowski \& Robinson, 2010). Some individuals are highly reactive. They get angry even under minimal provocation, expressing their anger in destructive manners, hurting themselves or other individuals, and these reactions are more frequent, intense, and long-lasting compared to the way that most people would react. Individuals with these characteristics have been identified as people with high trait anger (Deffenbacher et al., 1996; Spielberger, 1999). Other individuals represent the opposite side. They keep calm even when they are facing frustrating situations, seeking nonviolent solutions and analyzing problems with neutrality. Although they may get angry, they feel this emotion less often, for shorter periods of time, and they usually adopt the point of view of other people to understand an interpersonal conflict. Individuals with these characteristics have been identified as people with low trait anger (Deffenbacher et al., 1996; Spielberger, 1999). Since individuals with high and low trait anger usually differ in substantial manners (Deffenbacher et al., 1996; Owen, 2011; Spielberger, 1999; Tafrate, Kassinove, \& Dundin, 2002), trait anger is a useful construct to delimit individual differences where some people are more chronically prone to anger than others.

This paper is about trait anger in adolescents, understanding adolescence as a transitional period from 11 to 19 or 20 years old, between childhood and adulthood, that implies physical, cognitive and psychosocial changes (Papalia, Olds, \& Feldman, 2009). Two perspectives support that low trait anger is a positive trait in adults and adolescents, compared to high trait anger. First, based on the character strengths and virtues model (Gillham et al.,
2011; Park, Peterson, \& Seligman, 2004; Peterson \& Seligman, 2004), low trait anger is a strength because: (a) it contributes to the fulfillment of situations that constitute a good life, for oneself and for others; (b) it is related to mental health; (c) it is trait-like, that is, it has a degree of generality across situations and stability across time; (d) it is embodied in consensual paragons, that is, we value people who do not express every negative emotion they experience; (e) it has a "negative" antonym (high trait anger), and (f) it represents a positive trait across history and across cultures.

Second, empirical evidence reveals constructive correlates of low trait anger in adolescents (Alcázar-Olán \& Deffenbacher, 2013; Alcázar-Olán, Jurado, \& Reyes, 2015; Quinn, Rollock, \& Vrana, 2014), suggesting again that it is a positive trait. Specifically, compared to individuals with high trait anger, those with low trait anger: (a) have their anger triggered by fewer situations; (b) become angered less often; (c) become slightly or moderately angered; (d) experience anger for shorter periods of time; (e) avoid or distract from negative, angry recall of past and from potential future mistreatment, disrespect and provocations; (f) rarely engage in aggressive expressions of anger, and (g) cope or handle their anger in adaptive, constructive ways (Alcázar-Olán \& Deffenbacher, 2013; Alcázar-Olán et al., 2015; Quinn et al., 2014).

While differences between individuals with high and low trait anger have been replicated (Alcázar, Deffenbacher, Hernández-Guzmán, \& Wilson, 2011; Deffenbacher, Alcázar-Olán, Kocur, \& Richards, 2014; Deffenbacher, Lynch, Oetting, \& Yingling, 2001), some interpersonal aspects warrant further investigation.

In particular, anger is an interpersonal emotion where the adolescent's immediate environment (e.g., parents' behavior and their rearing styles) has an impact on the behavior and emotions of adolescents (Kitamura, Ohashi, Murakami, \& Goto, 2014; Van Lissa, Keizer, Van Lier, Meeus, \& Branje, 2019; Yang, Bin, Yi, \& Le-ping, 2009). In reciprocity, adolescents' reactions also impact their parents. Based on studies about experiencing and expressing anger, where high and low trait anger are chronic, and relatively stable (Deffenbacher, 1993; Deffenbacher et al., 
2014; Takebe, Takahashi, \& Sato, 2016), it is valid to assume that parent-adolescent interactions differ in individuals with high and low trait anger. It is relevant to explore parenting practices that contribute to rearing adolescents with low trait anger, unlike practices associated with rearing adolescents with high trait anger.

Although the trait anger construct has received little attention with regard to parenting practices, research on parenting practices and emotions in adolescents reveal helpful insights. For instance, negative parenting (e.g., inconsistent behavior and punitive reactions) is associated with anger, aggression, and externalizing problems in children (Becht, Prinzie, Dekovic, Akker, \& Shiner, 2016; Shortt, Stoolmiller, Smith-Shine, Eddy, \& Sheeber, 2010; Tao, Zhou, \& Wang, 2010). Moreover, low levels of emotional warmth and high levels of rejection and control from the parents are accompanied by high levels of anger/hostility in adolescents (Muris, Meesters, Morren, \& Moorman, 2004).

Based on these findings, this research tested two hypotheses about trait anger and parenting practices. Specifically, compared to adolescents with high trait anger, those with low trait anger experience: (a) less negative parenting practices (e.g., less imposition or blaming about something) and (b) more positive parenting practices (e.g., more autonomy and communication with their parents).

Parental practices might be related not only to low and high trait anger, but also to the social skills and anger management strategies employed by adolescents. For instance, parental punitive reactions predict externalizing problems, including anger (Tao et al., 2010). On the contrary, positive parenting practices are associated with higher levels of prosocial skills (Koblinsky, Kuvalanka, \& Randolph, 2006). Based on the assumption that low trait anger is a personal strength (Peterson \& Seligman, 2004), this research assessed a third hypothesis. Compared to adolescents with high trait anger, those with low trait anger display higher levels of social skills, which are reflected in lower levels of anger and aggression toward other individuals, and higher levels of anger self-control.

A usual assumption is that men are more aggressive than women. A classic meta-analytic study showed that men are somewhat more aggressive than women on average (Bettencourt \& Miller, 1996), but another review found that differences are inconsistent across studies (Eagly \& Steffen, 1986). Other meta-analytic studies did not find gender differences on anger and aggression (Archer, 2004; Campbell, 2006). Given the lack of clear tendencies about anger and gender, this study did not make specific predictions.

Regarding gender and parenting practices, both parents have more communication and supervision concerning friends with girls than with boys (Betancourt Ocampo, 2007). However, another study found that mothers supervise in a greater extent than fathers do (Calvete, GámezGuardix, \& Orue, 2010), indicating contradiction in the findings. The mother exerts more psychological control on girls than on boys, while the father exerts this type of control in the same extent on both genders (Betancourt Ocampo, 2007). This research included gender as a demographic variable to explore differences in parenting practices.

Based on the assumption that low trait anger is a personal strength, the aim of the study was to compare adolescents with high and low trait anger regarding parenting practices, social skills (assertion/aggression), and their anger expression and control. It also explored gender differences with regard to these variables.

\section{Method}

\section{Participants}

The initial sample had 710 participants (329 male and 381 female). The mean age was $13.06(S D=0.77)$. Participants were students from second and third year in a public middle school, located in the state of Hidalgo, which is 90 minutes from Mexico City. Most of the students had siblings $(93.4 \%$ ), and $59.6 \%$ lived in the same house with their mother, father, and siblings.

From the full sample $(n=710)$, based on the goals of the study, researchers recruited only those with high and low trait anger, and who lived with their mother and father. 
This was relevant to assess parenting practices from both parents. Low trait anger was operationally defined as scoring in the lower quartile (score $<16$ ) in the Trait Anger Scale (see Instruments), and high trait anger as scoring in the upper quartile (score $>24$ ) in the Trait Anger Scale. Lower and higher quartiles are the standard criteria to detect individuals with low and high trait anger (Deffenbacher et al., 1996; DiGiussepe \& Tafrate, 2003). This yielded 140 participants ( 73 male, 67 female) with low trait anger, and 94 (35 male, 59 female) with high trait anger.

\section{Instruments}

Multicultural Latin American Inventory of Anger Expression and Hostility for Adolescents of Middle School Level. This Spanish-language inventory measures the experience and expression of anger (Alcázar-Olán, Deffenbacher, \& Escamilla-Tecalco, 2016). The anger experience dimension has two scales (trait and state anger), while the anger expression dimension has three scales (anger control-in, anger control-out, and anger-out). The Trait Anger Scale (10 items, $\alpha=.86$ ) assesses how often the individual feels anger or the propensity to feel this emotion across time and situations; for example, "I am hotheaded." The score from the Trait Anger Scale was the independent variable, used to create the high and low anger groups (high scores $=$ upper quartile; low scores $=$ lower quartile). The other scales (state anger, anger control-in, anger control-out, anger-out) and the instruments described below were the dependent variables.

The State Anger Scale (10 items, $\alpha=.91$ ) assesses anger intensity and the desire to express anger physically or verbally; for example, "I want to hit someone." The Anger Control-In Scale ( 7 items, $\alpha=.88$ ) measures the attempts to reduce one's anger through relaxation; for example, "I breathe deeply to relax." The Anger Control-Out Scale (5 items, $\alpha=.78$ ) refers to controlling one's behavior during anger episodes; for example, "I stay calm." The AngerOut Scale (6 items, $\alpha=.75$ ) assesses the direct anger expression toward other individuals; for example, "I show my anger to other people." Answer choices range from 1 (almost never) to 4 (almost always). Higher scores reflect higher frequency of the emotion or content of the item.
The inventory has construct validity for Mexican adolescents (Alcázar-Olán et al., 2016).

Children's Assertive Behavior Scale. The scale measures assertiveness and aggression, and it was published in English by Michelson and Wood (1982). The original English version was translated into Spanish by Aguilar (1995), who contacted 10 experts to review the translation. Then, Lara and Silva (2002) refined the Aguilar's translation by adding three judges, experts in assertiveness and aggressiveness. The latter version was used in this study. The assertive style refers to respecting one's own rights and the rights of others, while the aggressive style refers to behavior and attitudes to damage others and lack of consideration toward other people. The scale evaluates the children's reactions, with an aggressive or assertive style, in two types of situations. Each situation is presented to the child and s/he chooses the answer about what s/he would normally do or say.

The first type of situations (20 items) are about giving or receiving compliments and complaints. As examples, we cite original items of Michelson \& Wood (1982):

"Someone you were supposed to meet arrives 30 minutes late, which makes you upset; the person says nothing about why s/he is late. You would usually:

(a) Say 'I am upset that you kept me waiting like this.'

(b) Say 'I was wondering when you'd get here.'

(c) Say 'This is the last time I'll wait for you.'

(d) Say nothing to the person.

(e) Say 'You are a jerk! You are late."” (Michelson \& Wood, 1982, p. 10).

The second type of situations (seven items) are related to things that anger the child or blame them for something. For example:

"You know that someone is feeling upset. You would usually:

(a) Say 'You seem upset; can I help?'

(b) Be with them and not talk about their being upset.

(c) Say 'What's wrong with you?'

(d) Not say anything and leave them alone. 
(e) Laugh and say 'You're just a big baby!'” (Michelson \& Wood, 1982, p. 10).

Unlike Michelson and Wood (1982), the scores for the Mexican version of the scale were coded as stated in Lara and Silva (2002, p. 54) as: $1=$ assertive response, $2=$ partially passive response, $3=$ completely passive response, $4=$ partially aggressive response, and $5=$ completely aggressive response. Lower scores indicate assertiveness, and higher scores aggressiveness.

The use of the Children's Assertive Behavior Scale is appropriate for the present study, given the following reasons: (a) the scale was adapted to Mexican samples (Aguilar, 1995; Lara \& Silva, 2002) including ages between 9 and 17 years old (Lara \& Silva, 2002); (b) the scale has construct validity and acceptable reliability, $\alpha=.80$ (Lara \& Silva, 2002); and the items appropriately discriminate $(t$-tests) individuals with high from those with low scores (Lara \& Silva, 2002).

Parental Practices Scale. Andrade and Betancourt (2008) constructed this scale in Spanish to measure behavior and practices that Mexican adolescents perceive in their parents. The scale has valid constructs to assess parental practices from both, mother and father (Andrade \& Betancourt, 2008). Regarding the father, the scale has four factors. First, Communication and Behavioral Control (16 items, $\alpha=.97$ ), which assesses whether the adolescent informs about his/her activities to his/her father (communication), and the knowledge the father has about the activities done by the adolescent or knowledge about his/her everyday life (behavioral control); for example, "My father and I talk about my problems" (communication), and "My father knows about the things I do in my spare time" (behavioral control). Second, Autonomy (8 items, $\alpha=.94$ ), which refers to the respect the father shows toward the decisions made by the adolescent; for example, "My father respects my opinion, even if it is different from what he thinks." Third, Imposition ( 8 items, $\alpha=.90$ ) that measures the extent to which the father imposes his beliefs or behavior upon the adolescent; for example, "My father thinks he is right in everything." Fourth, Psychological Control ( 8 items, $\alpha=.90$ ), which assesses detrimental behavior from the father toward the adolescent, like criticiz- ing and devaluing, or inducing guilt upon the adolescent; for example, "My father blames me for anything."

Regarding the mother, the scale has five factors. First, Communication (11 items, $\alpha=.92$ ); for example, "My mother and I talk like good friends." Second, Autonomy (7 items, $\alpha=.86$ ); for example, "My mother supports my decisions." Third, Imposition ( 8 items, $\alpha=.81$ ); for example, "My mother wants me to be like she is." Fourth, Behavioral Control (7 items, $\alpha=.84$ ); for example, "My mother knows what I do in the afternoons, after school." Fifth, Psychological Control ( 8 items, $\alpha=.80$ ); for example, "My mother makes me feel useless."

Communication, autonomy and behavioral control scales assess positive (healthy) parenting styles, while imposition and psychological control scales assess negative (unhealthy) parenting styles. The answer choices range from 1 (never) to 4 (always); higher scores indicate higher frequency of the behavior and practices assessed.

\section{Procedure}

Both the institutional review processes and the middle school authorities approved the research. None of the scales required reverse scoring. Researchers trained 16 research assistants, undergraduate students of psychology (four teams consisting of four people), who administered all the instruments in Spanish. The assistants introduced the topic of research and requested the participation of the students, clarifying that the participation was anonymous and voluntary, and that they could decline participating at any moment. When the students had completed the questionnaires, they raised their hands while seated, and one of the assistants collected the questionnaire and thanked them for their participation. The teachers were present at least during the reading of the instructions, and one of the researchers supervised and helped when needed. Each group had approximately 50 students, and the administration of the questionnaires took 50 minutes in each group.

The design of the study was $2 \times 2$ (gender $\mathrm{x}$ anger groups) and used a multivariate analysis of variance (MANOVA) with the Wilks' Lambda $(\lambda)$ statistic and eta squared $\left(\eta^{2}\right)$ as measure of effect size. This was interpreted with Cohen's criteria: .01-.04 small, .04 to .14 moderate, 
Table 1.

Anger, gender and parental practices in adolescents.

\begin{tabular}{|c|c|c|c|c|c|c|}
\hline \multirow{2}{*}{ Measures } & \multicolumn{2}{|c|}{ Male } & \multicolumn{2}{|c|}{ Female } & \multirow{2}{*}{$\begin{array}{c}\text { ANOVA } \\
F(1,421) \\
\end{array}$} & \multirow{2}{*}{$\begin{array}{c}\text { Effect } \\
\text { Size }\left(\eta^{2}\right)\end{array}$} \\
\hline & $M$ & $S D$ & $M$ & $S D$ & & \\
\hline \multicolumn{7}{|l|}{ Assertive/aggressive behavior } \\
\hline Aggression when giving/receiving compliments & 36.11 & 8.22 & 34.87 & 8.20 & 2.40 & .006 \\
\hline Aggression in anger/guilt situations & 17.67 & 5.35 & 17.83 & 5.27 & 0.09 & .000 \\
\hline \multicolumn{7}{|l|}{ Positive/healthy parenting } \\
\hline Communication and behavioral control (father) & 2.82 & 0.77 & 2.63 & 0.89 & $5.18^{*}$ & .012 \\
\hline Communication (mother) & 3.10 & 0.67 & 3.07 & 0.83 & 0.17 & .000 \\
\hline Behavioral control (mother) & 3.09 & 0.65 & 3.24 & 0.66 & $5.72^{*}$ & .013 \\
\hline Autonomy (father) & 3.14 & 0.65 & 3.02 & 0.77 & 2.79 & .007 \\
\hline Autonomy (mother) & 2.99 & 0.61 & 2.84 & 0.73 & $4.63^{*}$ & .011 \\
\hline \multicolumn{7}{|l|}{ Negative/unhealthy parenting } \\
\hline Imposition (father) & 1.77 & 0.53 & 1.67 & 0.57 & 3.44 & .008 \\
\hline Imposition (mother) & 1.96 & 0.60 & 2.01 & 0.62 & 0.96 & .002 \\
\hline Psychological control (father) & 1.31 & 0.42 & 1.36 & 0.50 & 0.81 & .002 \\
\hline Psychological control (mother) & 1.48 & 0.50 & 1.61 & 0.67 & $5.17^{*}$ & .012 \\
\hline \multicolumn{7}{|l|}{ Anger experience } \\
\hline Trait anger & 18.67 & 6.10 & 20.47 & 6.82 & $7.97^{*}$ & .019 \\
\hline State anger & 11.67 & 3.06 & 12.00 & 3.64 & 1.03 & .002 \\
\hline \multicolumn{7}{|l|}{ Anger expression } \\
\hline Anger control-in & 18.63 & 6.12 & 18.06 & 5.97 & 0.90 & .002 \\
\hline Anger control-out & 12.29 & 3.86 & 11.67 & 3.88 & 2.65 & .006 \\
\hline Anger-out & 10.56 & 2.95 & 11.12 & 3.60 & 2.95 & .007 \\
\hline
\end{tabular}

Note. ${ }^{*} p<.05$.

and greater than .14 large (1988). When multivariate effects were found, univariate effects were analyzed.

\section{Results}

The 2 x 2 MANOVA showed significant effects for group and gender, $\lambda \mathrm{s}=.087$ and $.836, F \mathrm{~s}(16$, $215)=141.01$ and $2.64, p \mathrm{~s}<.001$ and .01 , and $\eta^{2} \mathrm{~s}=.913$ and .164 , but not for the interaction, $F(16,215)=0.96$. Since the MANOVA was significant for the group and gender, the next step was to identify the main effects for these variables through univariate ANOVA's. These effects are presented in Tables 1 and 2. With regard to gender, from the 16 measures, the univariate analyses revealed differences in five variables (Table 1). Mother and father had more communication with and gave greater autonomy to male than to female adolescents. However, the mother exerted more psychological and behavioral control on female than on male adolescents. Effect sizes were moderate. Female adolescents experienced higher trait anger than male adolescents (Table 1).

The univariate analyses also yielded substantial differences in parenting practices between adolescents with high and low trait anger (Table 2). Compared to those with high trait anger, adolescents with low trait anger perceived less imposition and psychological control (less detrimental messages) from both mother and father. In addition, adolescents with low trait anger experienced more communication, autonomy, and behavioral control (more knowledge about the adolescent's life) with their mother and father than adolescents with high trait anger. Effect sizes were small to moderate.

In terms of anger expression and social skills (Table 2), compared to adolescents with high trait anger, those with low trait anger exhibited less aggressive reactions when giving/receiving compliments and when they were blamed for something, and they showed lower expressions of anger toward other individuals (anger-out), which was 
Table 2.

Low and high trait anger groups, aggression, and parental practices.

\begin{tabular}{|c|c|c|c|c|c|c|}
\hline \multirow{2}{*}{ Measures } & \multicolumn{2}{|c|}{ Low TA } & \multicolumn{2}{|c|}{ High TA } & \multirow{2}{*}{$\begin{array}{c}\text { ANOVA } \\
F(1,232)\end{array}$} & \multirow{2}{*}{$\begin{array}{c}\text { Effect } \\
\text { Size }\left(\eta^{2}\right)\end{array}$} \\
\hline & $\bar{M}$ & $S D$ & $\bar{M}$ & $\bar{S} D$ & & \\
\hline \multicolumn{7}{|l|}{ Assertive/aggressive behavior } \\
\hline Aggression when giving/receiving compliments & 33.27 & 7.67 & 38.46 & 9.71 & $20.71^{* * *}$ & .082 \\
\hline Aggression in anger/guilt situations & 15.62 & 4.89 & 20.17 & 5.60 & $43.19^{* * *}$ & .157 \\
\hline \multicolumn{7}{|l|}{ Positive/healthy parenting } \\
\hline Communication and behavioral control (father) & 2.89 & 0.82 & 2.58 & 0.87 & $7.24^{* *}$ & .030 \\
\hline Communication (mother) & 3.20 & 0.75 & 2.93 & 0.87 & $5.97^{*}$ & .025 \\
\hline Behavioral control (mother) & 3.25 & 0.67 & 3.02 & 0.66 & $6.76^{*}$ & .028 \\
\hline Autonomy (father) & 3.24 & 0.65 & 2.89 & 0.82 & $12.75^{* * *}$ & .052 \\
\hline Autonomy (mother) & 3.07 & 0.65 & 2.69 & 0.80 & $15.99^{* * *}$ & .064 \\
\hline \multicolumn{7}{|l|}{ Negative/unhealthy parenting } \\
\hline Imposition (father) & 1.66 & 0.53 & 1.85 & 0.62 & $6.17^{*}$ & .026 \\
\hline Imposition (mother) & 1.90 & 0.55 & 2.09 & 0.71 & $5.47^{*}$ & .023 \\
\hline Psychological control (father) & 1.23 & 0.45 & 1.47 & 0.53 & $14.16^{* * *}$ & .058 \\
\hline Psychological control (mother) & 1.37 & 0.51 & 1.86 & 0.76 & $34.16^{* * *}$ & .128 \\
\hline \multicolumn{7}{|l|}{ Anger experience } \\
\hline State anger & 10.82 & 1.65 & 13.91 & 5.02 & $45.77^{* * *}$ & .165 \\
\hline \multicolumn{7}{|l|}{ Anger expression } \\
\hline Anger control in & 20.15 & 6.31 & 16.62 & 5.66 & $18.98^{* * *}$ & .076 \\
\hline Anger control out & 13.47 & 4.29 & 10.61 & 3.31 & $29.73^{* * *}$ & .114 \\
\hline Anger out & 9.71 & 2.82 & 13.24 & 3.83 & $65.52^{* * *}$ & .220 \\
\hline
\end{tabular}

Note. TA $=$ Trait anger. ${ }^{*} p<.05,{ }^{* *} p<.01,{ }^{* * *} p<.001$.

also reflected in higher levels of anger control-in (i.e., relaxing) and higher anger control-out (managing one's behavior when angry). Effect sizes were moderate to large.

\section{Discussion}

This research studied low trait anger as a personal strength in adolescents. The findings supported that compared to adolescents with high trait anger, those with low trait anger experience less imposition and psychological control (being blamed) from their parents (Hypothesis 1), more autonomy, communication and behavioral control from their parents (Hypothesis 2), and more social skills, reflected in lower levels of anger-out, lower aggression toward other individuals, and higher levels of anger selfcontrol (Hypothesis 3). The findings may be discussed from two perspectives.
First, the results are consistent with the literature that examined the characteristics of individuals with high versus low trait anger (Alcázar-Olán \& Deffenbacher, 2013; Deffenbacher et al., 1996; Quinn et al., 2014). However, the contribution of the present study is that of characterizing one of the environments (parenting practices perceived by the adolescents) to experience low trait anger. Since parents are the immediate interpersonal context of their offspring, parents influence the emotions felt by their children and adolescents (Cummings \& Smith, 1993; Shortt et al., 2010). Moreover, given that parent-adolescent interactions are relatively permanent, then it is plausible to conceive that parental practices may contribute to chronically experiencing high or low trait anger (Kitamura et al., 2014).

Second, the results and previous findings (AlcázarOlán \& Deffenbacher, 2013; Alcázar-Olán et al., 2015; Quinn et al., 2014) indicate that compared to adolescents with high trait anger, those with low trait anger showed more social skills, anger self-control, and lower aggression toward others. The results support that low trait anger is a positive trait (Park et al., 2004; Peterson \& 
Seligman, 2004) because it was measurable and differentiated from high trait anger, it was related to positive outcomes, and it had an antonym that was "negative" (high trait anger). Therefore, the low trait anger construct deserves attention and further study from the strengths and virtues model (Park et al., 2004; Peterson \& Seligman, 2004). For instance, new research may identify the mechanisms of interpersonal variables (e.g., family, peers or community contexts) that contribute to develop low trait anger, that is, anger management strategies as personality traits, which result in more social skills and lower aggression in adolescents.

Current and previous findings (Kitamura et al., 2014; Yang et al., 2009) indicate an association between rearing styles and trait anger in adolescents. Based on these results, it is valid to address the mechanisms of this relationship. For example, why do parenting styles result in low or high trait anger in adolescents? We propose that negative/unhealthy parenting produces negative affect in adolescents and, subsequently, this results in high trait anger. This might be particularly true when negative/unhealthy parenting is pervasive, thus producing constantly high levels of both, negative affect and trait anger. Although it is hard to establish cause-effect relationships, our perspective is that adolescents might be reacting (through high negative affect and trait anger) to the negative/unhealthy parenting behavior. This explanation is consistent with Berkowitz's view that negative affect (unpleasant feelings produced by aversive events), like negative parenting behavior, is the origin or trigger of anger (Berkowitz, 1983, 2001).

Moreover, the absence of negative affect may be useful to explain low trait anger in adolescents. Specifically, positive/healthy parenting may reduce negative affect, and the reduction of negative affect leads to low trait anger in adolescents. Future research may examine these pathways.

Aggression and social skills did not differ by gender. Men and women appear more similar than different on these variables, which supports other studies (Archer, 2004; Campbell, 2006). In relation to gender and parenting practices, this research replicated a previous finding (Betancourt Ocampo, 2007), that both parents have more communication with boys than with girls. Another finding that was replicated is that mothers exert more psychological and behavioral control on female than on male adolescents (Betancourt Ocampo, 2007). These findings indicate positive rearing practices for males in a greater extent than for females, who received more negative parenting behavior (e.g., psychological control). The gender and cultural context might help to understand the results because some societies give more privileges and positive attention to males than females (Ridgeway, 2011), and these patterns might be reflected in the rearing practices. This may help to comprehend another finding: female adolescents experienced higher trait anger than male adolescents.

This research has some limitations, for example, the use of self-reporting. However, this strategy is appropriate to investigate internal states like anger. The assessment of aggression, social skills and parenting practices should include observational methods in future studies. Another limitation is that we assessed adolescents' perceptions about their parents, but not their actual parenting practices. Therefore, the adolescents might be over or underreporting their parents' behavior. Moreover, adolescents with high trait anger might perceive the parents' behavior in a more negative manner, compared to adolescents with low trait anger.

The study of perceptions, however, is not necessarily misleading. For instance, the perceptions (as opposed to objective measures) are critical in determining the psychopathology in children. Children with internal and external symptoms generally have negative perceptions of their parents (Yahav, 2006). Another study found that adolescents with high trait anger perceive angrier parents, compared to adolescents with low trait anger (Alcázar-Olán \& Deffenbacher, 2013). Research about the relationships between parents and their offspring (Finley, Mira, \& Schwhartz, 2008; Rohner, 2000; Rohner, Khaleque, \& Cournoyer, 2005) show that perceptions are as important or more important than actual parent behavior.

Another limitation was the small range of age of the participants $(M=13.06, S D=.77)$, which corresponds to the beginning of the adolescence. Therefore, the results correspond only to this age, and not to all the adolescents (ages between 11 and 19). 
Although the parents may exert an influence on the emotions of their adolescents, the design of the study limits drawing cause-effect conclusions. An alternative explanation is a circular perspective, where parents and adolescents have reciprocal influence that results in low (or high) trait anger in adolescents. The findings lead to conclude, at most, that low trait anger is related to positive parenting practices (as perceived by the adolescents), and that it is related to higher levels of social skills, and lower anger and aggression.

\section{Referencias}

Aguilar, N. (1995). Estandarización de la Escala de Asertividad de Michelson y Wood en una muestra mexicana de niños de 8 a 16 años. [Standardization of the Michelson and Wood's Children's Assertive Behavior Scale in a Mexican sample with children from 8 to 16 years old]. Unpublished bachelor's thesis. Universidad Nacional Autónoma de México.

Alcázar, R. J., Deffenbacher, J. L., Hernández-Guzmán, L., \& Wilson, G. I. (2011). High and Low Trait Anger, and the Recognition of Anger Problems. The Spanish Journal of Psychology, 14, 851-858. https://doi.org/10.5209/rev_SJOP.2011.v14.n2.32

Alcázar-Olán, R. J. \& Deffenbacher, J. L. (2013). High Trait Anger Mexican Youth: Characteristics, Parental anger, and Counseling Needs. The Spanish Journal of Psychology, 16, 1-10. https://doi.org/10. 1017/sjp.2013.89

Alcázar-Olán, R. J., Deffenbacher, J. L. \& EscamillaTecalco, H. (2016). Developing a Valid Version of an Inventory to Measure Anger in Mexican Adolescents of Middle School Level: The MLSTAXI-MS. Youth \& Society, 48, 126-143. https://doi.org/10.1177/0044118X13483775

Alcázar-Olán, R. J., Jurado, S., \& Reyes, V. (2015). El enojo como rasgo de personalidad y agresión física en adolescentes de preparatoria [Anger as Personality trait and Physical Aggression in High School Adolescents]. Psicumex, 5, 89-101.

Andrade, P. \& Betancourt, D. (2008). Prácticas parentales: una medición integral [Parental Practices: An Integral Measurement]. In S. Rivera, R. DíazLoving, I. Reyes, R. Sánchez, \& M. Cruz (Eds.), La Psicología Social en México (Vol. XII, pp. 561-565). México: AMEPSO.

Archer, J. (2004). Sex Differences in Aggression in RealWorld Settings: A Meta-Analytic Review. Review of General Psychology, 8, 291-322. https://doi.org/10. 1037/1089-2680.8.4.291

Becht, A. I., Prinzie, P., \& Dekovic, M., Akker, A. V. D., \& Shiner, R. L. (2016). Child Personality Facets and Overreactive Parenting as Predictors of Aggression and Rule-Breaking Trajectories from Childhood to Adolscence. Development and Psychopathology, 28, 399-413. https://doi.org/10.1017/S09545794150005 77

Berkowitz, L. (1983). Aggression: Its Causes, Consequences, and Control. New York, NY: McGraw-Hill.

Berkowitz, L. (2001). On the Formation and Regulation of Anger and Aggression: A Cognitiveneoassociationistic analysis. In P. W. Gerrod (Ed.), Emotions in Social Psychology: Essential Readings (pp. 325-336). New York, NY: Psychology Press.

Betancourt Ocampo, D. (2007). Control parental, y problemas internalizados y externalizados en niños y adolescentes [Parental Control, and Internalized and Externalized Problems in Children and adolescents]. (Doctoral Thesis). Universidad Nacional Autónoma de México, no publicada.

Bettencourt, B. A. \& Miller, N. (1996). Gender Differences in Aggression as a Function of Provocation: A Meta-analysis. Psychological Bulletin, 119, 422-447. https://doi.org/10.1037/ 0033-2909.119.3.422 
Calvete, E., Gámez-Guadix, M., \& Orue, I. (2010). El inventario de dimensiones de disciplina (DDI), versión niños y adolescentes: estudio de las prácticas de disciplina parental desde una perspectiva de género [The Dimensions of Discipline Inventory (DDI)-Child and Adolescent Version: Analysis of the Parental Discipline from a Gender Perspective]. Anales de Psicología, 26(2), 410-418.

Campbell, A. (2006). Sex Differences in Direct Aggression: What are the Psychological Mediators? Aggression and Violent Behavior, 11, 237-264. https://doi.org/10.1016/j.avb.2005.09.002

Cohen, J. (1988). Statistical Power Analysis for the Behavioral Sciences (2nd Ed.). New York: Academic Press.

Cummings, E. M. \& Smith, D. (1993). The Impact of Anger between Adults on Siblings' Emotions and Social Behavior. Journal of Child Psychology and Psychiatry, 34, 1425-1433. https://doi.org/10.1111/ j.1469-7610.1993.tb02100.x

Deffenbacher, J. L. (1993). General Anger: Characteristics and Clinical Implications. Psicologia Conductual, 1, 49-67.

Deffenbacher, J. L., Alcázar-Olán, R. J., Kocur, J. L., \& Richards, T. L. (2014). A Test of the State-Trait Model of Anger with Middle-Aged Drivers. In M. G. Penrod \& S. N. Paulk (Eds.), Psychology of Anger (pp. 71-87). New York, NY: Nova Science.

Deffenbacher, J. L., Lynch, R. S., Oetting, E. R. \& Yingling, D. A. (2001). Driving Anger: Correlates and a Test of State-Trait Theory. Personality and Individual Differences, 31, 1321-1331. https://doi.org/10.1037/0022-0167.43.2.131

Deffenbacher, J. L., Oetting, E. R., Thwaites, G. A., Lynch, R. S., Baker, D. A., ...Eiswerth-Cox, L. (1996). State-Trait Anger Theory and the Utility of the Trait Anger Scale. Journal of Counseling Psychology, 43, 131-148. https://doi.org/10.1037/ 0022-0167.43.2.131
DiGiussepe, R. C. \& Tafrate, R. C. (2003). Anger Treatment for Adults: A Meta-analytic Review. Clinical Psychology: Science and Practice, 10, 7084. https://doi.org/10.1093/clipsy.10.1.70

Eagly, A. H. \& Steffen, V. J. (1986). Gender and Aggressive Behavior: A Meta-analytic Review of the Social Psychological Literature. Psychological Bulletin, 100, 309-330. https://doi.org/10.1037/ 0033-2909.100.3.309

Finley, G. E., Mira, S. D., \& Schwartz, S. J. (2008). Perceived Paternal and Maternal Involvement: Factor Structures, Mean Differences, and Parental Roles. Fathering, 6, 62-82. https://doi.org/10.3149/ fth.0601.62

Gillham, J., Adams-Deutsch, Z., Werner, J., Reivich, K., Coulter-Heindl, V., Linkins, M.,...Seligman, M. E. P. (2011). Character Strengths Predict Subjective Well-being during Adolescence. The Journal of Positive Psychology, 6, 31-44. https://doi.org/10. 1080/17439760.2010.536773

Kitamura, T., Ohashi, Y., Murakami, M., \& Goto, Y. (2014). Anger and Perceived Parenting: A Study of a Japanese Population. Psychology and Behavioral Sciences, 2, 217-222. https://doi.org/10.11648/ j.pbs.20130206.13

Koblinsky, S. A., Kuvalanka, K. A., \& Randolph, S. M. (2006). Social Skills and Behavior Problems of Urban, African American Preschoolers: Role of Parenting Practices, Family Conflict, and Maternal Depression. American Journal of Orthopsychiatry. 76, 554-563. https://doi.org/10.1037/0002-9432.76. 4.554

Kuppens, P. (2005). Interpersonal Determinants of Trait Anger: Low Agreeableness, Perceived Low Social Esteem, and the Amplifying Role of the Importance Attached to Social Relationships. Personality and Individual Differences, 38, 13-23. https://doi.org/ 10.1016/j.paid.2004.03.006 
Lara, M. C. \& Silva, A. (2002). Estandarización de la escala de asertividad de Michelson y Wood en niños $y$ adolescentes: II [Standardization of the Michelson and Wood's Children's Assertive Behavior Scale in children and adolescents: II]. Unpublished bachelor's thesis. Universidad Nacional Autónoma de México.

Michelson, L. \& Wood, R. (1982). Development and Psychometric Properties of the Children's Assertive Behavior Scale. Journal of Behavioral Assessment, 4, 3-13. https://doi.org/10.1007/BF01321378

Muris, P., Meesters, C., Morren, M., \& Moorman, L. (2004). Anger and Hostility in Adolescents: Relationship with Self-Reported Attachment Style and Perceived Parental Rearing Styles. Journal of Psychosomatic Research, 57, 257-264. https://doi.org/10.1016/S0022-3999(03)00616-0

Owen, J. M. (2011). Transdiagnostic Cognitive Processes in High Trait Anger. Clinical Psychology Review, 31, 193-202. https://doi.org/10.1016/j.cpr.2010.10.003

Papalia, D. E., Olds, S. W., \& Feldman, R. D. (2009). Psicología del desarrollo: De la infancia a la adolescencia (Trad. F. López, 11th Ed.) [A Child's World: Infancy through Adolescence]. México: McGraw Hill.

Park, N., Peterson, C., \& Seligman, M. (2004). Strengths of Character and Well-Being. Journal of Social and Clinical Psychology, 23, 603-619. https://doi.org/10. $1521 /$ jscp.23.5.603.50748

Peterson, C. \& Seligman, M. E. (2004). Character Strengths and Virtues: A Handbook and Classification. Washington, DC: American Psychological Association.

Quinn, C. A., Rollock, D., \& Vrana, S. R. (2014). A Test of Spielberger's State-Trait Theory of Anger with Adolescents: Five Hypotheses. Emotion, 14, 74-84. https://doi.org/10.1037/a0034031.
Ridgeway, C. L. (2011). Framed by Gender: How Gender Inequality Persists in the Modern World. New York, NY: Oxford University Press.

Rohner, R. P. (2000). They Love me, they Love me not: A Worldwide Study of the Effects of Parental Acceptance and Rejection. Storrs CT: Rohner Research.

Rohner, R. P., Khaleque, A., \& Cournoyer, D. E. (2005). Parental Acceptance-Rejection: Theory, Methods, Cross-cultural Evidence, and Implications. ETHOS: Journal of the Society for Psychological Anthropology, 33, 299-334. https://doi.org/10.1525/ eth.2005.33.3.299

Shortt, J. W., Stoolmiller, M., Smith-Shine, J. N., Eddy, J. M., \& Sheeber, L. (2010). Maternal Emotion Coaching, Adolescent Anger Regultaion, and Siblings' Externalizing Symptoms. Journal of Child Psychology and Psychiatry, 51, 799-808. https://doi.org/10.1111/j.1469-7610.2009.02207.x

Spielberger, C. D. (1999). Manual for the State-Trait Anger Expression Inventory (Revised Ed). Odessa, Fl: Psychological Assessment Resources.

Tafrate, R. C., Kassinove, H., \& Dundin, L. (2002). Anger Episodes in High- and Low-Trait-Anger Community Adults. Journal of Clinical Psychology, 58, 15731590. https://doi.org/10.1002/jclp.10076

Takebe, M., Takahashi, F., \& Sato, H. (2016). Anger Rumination as a Risk Factor for Trait Anger and Anger-in: A Longitudinal Study. Personality and Individual Differences, 101, 451-455. https://doi.org/10.1016/j.paid.2016.06.038

Tao, A., Zhou, Q., \& Wang, Y. (2010). Parental Reactions to Children's Negative Emotions: Prospective Relations to Chinese Children's Psychological Adjustment. Journal of Family Psychology, 24, 135144. https://doi.org/10.1037/a0018974

Van Lissa, C. J., Keizer, R., Van Lier, P. A. C., Meeus, W. H. J., \& Branje, S. (2019). The Role of Fathers' 
versus Mothers' Parenting in Emotion-Regulation Development from Mid-late Adolescence: Disentangling Between-family Differences from Within-Family Effects. Developmental Psychology, 55, 377-389. https://doi.org/10.1037/dev0000612

Wilkowski, B. M. \& Robinson, M. D. (2010). The Anatomy of Anger: An Integrative Cognitive Model of Trait Anger and Reactive Aggression. Journal of Personality, 78, 9-38. https://doi.org/10.1111/j.1467 $-6494.2009 .00607 . \mathrm{x}$

Yahav, R. (2006). The Relationship between Children's and Adolescents' Perceptions of Parenting Style and Internal and External Symptoms. Child: Care, Health and Development, 33, 460-471. https://doi.org/10.1111/j.1365-2214.2006.00708.x

Yang, S., Bin, X., Yi., Q., \& Le-ping, H. (2009). A Correlation Study of State-trait Anger to Parental Rearing Styles of Young Male Violent Offenders. Chinese Journal of Clinical Psychology, 17 (4), 481883. 